\title{
NON LINEAR STATIC PUSHOVER ANALYSIS OF IRREGULAR SPACE FRAME STRUCTURE WITH AND WITHOUT T SHAPED COLUMNS
}

\author{
Govind $\mathbf{M}^{1}$, Kiran K. Shetty ${ }^{2}$, K. Anil Hegde ${ }^{3}$ \\ ${ }^{I}$ M. Tech Final Year (Structures), Department of civil engineering, M.I.T Manipal, Karnataka, India \\ ${ }^{2}$ Associate Professor (senior scale), Department of civil engineering, M.I.T Manipal Karnataka, India \\ ${ }^{3}$ Senior Structural Consultant, Vimal Anil Structural Consultants, Mangalore, Karnataka, India
}

\begin{abstract}
The static pushover analysis is becoming a popular tool for seismic performance evaluation of existing and new structures. The expectation is that the pushover analysis will provide adequate information on seismic demands imposed by the design ground motion on the structural system and its components. The recent advent of structural design for a particular level of earthquake performance, such as immediate post-earthquake occupancy, (termed as performance based earthquake engineering), has resulted in guidelines such as ATC-40, FEMA-356 and standards such as ASCE-41. Among the different types of analysis, pushover analysis comes forward because of its optimal accuracy, efficiency and ease of use. In the present study, the behaviour of G+20 storied R.C frame buildings (H shape in plan, with and without T shaped column) subjected to earthquake, located in seismic zone III is discussed briefly using ETABS software. Gravity loads and laterals loads as per IS 1893-2002 are applied on the structure and it is designed using IS 456. Displacement control pushover analysis is carried out.
\end{abstract}

Keywords: Column shape, Irregular structure, Pushover analysis, Seismic evaluation

\section{INTRODUCTION}

\subsection{General}

The existence of an asymmetry in the plan is usually leading to an increase in stresses of certain elements that consequently results in a significant destruction [1]. The analysis of the seismic response of irregular structures is complex due to nonlinear and inelastic response and more difficult than that of regular structures. Many researchers had tried to develop more rational analysis method that would achieve a satisfactory balance between required reliability and applicability for everyday design use. In recent years, a breakthrough of simplified methods for seismic analysis based on nonlinear static procedure (NSP) has occurred. This procedure; that is known as "pushover", can be effectively used as an evaluation method to check the acceptability of a particular structural design. The method allows tracing the sequence of yielding and failure on the member and the structure levels as well as the progress of the overall capacity curve of the structure. The static pushover procedure has been presented and developed over the past twenty years by Saiidi and Sozen [1], Fajfar and Gaspersic [2] and Bracci et al. [3], among others. The method is also described and recommended as a tool for design and assessment purposes by the National Earthquake Hazard Reduction Program 'NEHRP' (FEMA 273) [4] guidelines for the seismic rehabilitation of existing buildings. Moreover, the technique is accepted by the Structural Engineers Association of California 'SEAOC' (Vision 2000) [5] among other analysis procedures with various level of complexity. This analysis procedure is selected for its applicability to performance-based seismic design approaches and can be used at different design levels to verify the performance targets. In this paper, the results of pushover analysis of reinforced concrete frames designed according to the IS1893:2002 has been presented. The behaviour G+20 storied R.C frame buildings $(\mathrm{H}$ shape in plan, with and without $\mathrm{T}$ shaped column) subjected to earthquake, located in seismic zone III is also discussed briefly using ETABS software.

\subsection{Pushover Methodology}

A pushover analysis is performed by subjecting a structure to a monotonically increasing pattern of lateral loads, representing the inertial forces which would be experienced by the structure when subjected to ground shaking. Under incrementally increasing loads various structural elements may yield sequentially. Consequently, at each event, the structure experiences a loss in stiffness. Using a pushover analysis, a characteristic non-linear force displacement relationship can be determined.

\subsection{Structural Irregularity}

The plan irregularity can be defined as per IS 1893-2002, that plan configurations of a structure and its lateral force resisting system contain re-entrant corners, where both projections of the structure beyond the re-entrant corner are greater than 15 percent of its plan dimension in the given direction. Buildings with large re-entrant corners, (i.e., plan shapes such as L, V, + , 
$\mathrm{Y}$, etc.) show poor performance during earthquakes. Each wing of such a building tends to vibrate as per its own dynamic characteristic, causing a stress concentration at the junctions of the wings.

\subsection{Research Significance}

In the present study, RCC frame model is developed using ETABS software and pushover analysis is done on the $\mathrm{H}$ shaped plan model with rectangular column (with and without $\mathrm{T}$ shaped column). The result obtained from the analysis is analyzed and compared each other

\subsection{Design Earthquake Loading}

It is expected that the peak ground acceleration does not occur simultaneously in two perpendicular horizontal directions. Consider a building in which horizontal load is resisted by frames or walls oriented in two orthogonal directions, say X and $\mathrm{Y}$ (see Fig.1).So the design ground motion be considered to act separately in $\mathrm{X}$ direction and in $\mathrm{y}$ direction, i.e., the design motion in $\mathrm{X}$ direction is assumed to not act simultaneously with that in the $\mathrm{Y}$ direction. If at a given instant, motion in any direction other than $\mathrm{X}$ or $\mathrm{Y}$, one can resolve it into $\mathrm{X}$ and $\mathrm{Y}$ components, and the building will still be safe if it is designed for $\mathrm{X}$ and $\mathrm{Y}$ motions separately
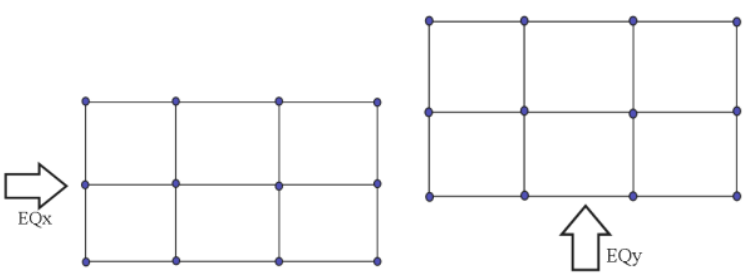

Fig-1: Earthquake loading in both directions

\subsection{Nonlinear Static Pushover Analysis}

The guidelines and standards mentioned in the introduction include modelling procedures, acceptance criteria and analysis procedures for pushover analysis. These documents define force-deformation criteria for potential locations of lumped inelastic behaviour, designated as plastic hinges used in pushover analysis. As shown in Figure 5 below, five points labelled $\mathrm{A}, \mathrm{B}, \mathrm{C}, \mathrm{D}$, and $\mathrm{E}$ are used to define the force deformation behaviour of the plastic hinge, and three points labelled IO (Immediate Occupancy), LS (Life Safety) and CP (Collapse Prevention) are used to define the acceptance criteria for the hinge. In these documents, if all the members meet the acceptance criteria for a particular performance level, such as Life Safety, then the entire structure is expected to achieve the Life Safety level of performance. The values assigned to each of these points vary depending on the type of member as well as many other parameters, such as the expected type of failure, the level of stresses with respect to the strength, or code compliance.

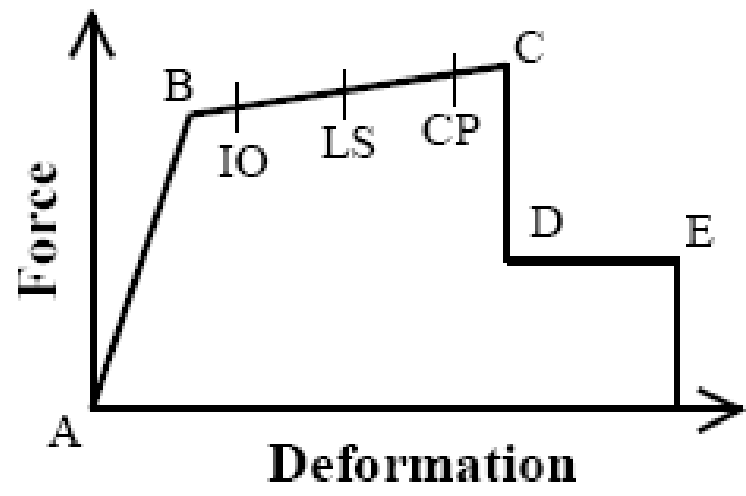

Fig-2: Force-Deformation Relation for Plastic Hinge in Pushover Analysis

Both the ATC-40 and FEMA 356 documents present similar performance-based engineering methods that rely on nonlinear static analysis procedures for prediction of structural demands. While procedures in both documents involve generation of a "pushover" curve to predict the inelastic force-deformation behaviour of the structure, they differ in the technique used to calculate the global inelastic displacement demand for a given ground motion. The FEMA 356 document uses the Coefficient Method, whereby displacement demand is calculated by modifying elastic predictions of displacement demand. The ATC-40 Report details the Capacity-Spectrum Method, where by modal displacement demand is determined from the intersection of a capacity curve, derived from the pushover curve, with a demand curve that consists of the smoothed response spectrum representing the design ground motion, modified to account for hysteretic damping effects.

\subsection{Purpose of Pushover Analysis}

The pushover is expected to provide information on many response characteristics that cannot be obtained from an elastic static or dynamic analysis. The following are the examples of such response characteristics.

- Estimates of inter story drifts and its distribution along the height.

- Determination of force demands on brittle members, such as axial force demands on columns, moment demands on beam-column connections.

- Determination of deformation demands for ductile members.

- Identification of location of weak points in the structure (or potential failure modes)

- Consequences of strength deterioration of individual members on the behaviour of structural system.

- Identification of strength discontinuities in plan or elevation that will lead to changes in dynamic characteristics in the inelastic range.

- Verification of the completeness and adequacy of load path. 


\section{BUILDING PLAN AND DIMENSION DETAILS}

The Following are the specification of G+20 commercial building, resting on Soil type II and located in seismic zone III The complete detail of the structure including modelling concepts and a brief summary of the building is presented below:

Table-1: Details and dimensions of building

\begin{tabular}{|l|l|}
\hline Type of structure & $\begin{array}{l}\text { Ordinary moment resisting RC } \\
\text { frame }\end{array}$ \\
\hline Grade of concrete & M $40(\mathrm{fck}=40 \mathrm{~N} / \mathrm{mm} 2)$ \\
\hline $\begin{array}{l}\text { Grade of reinforcing } \\
\text { steel }\end{array}$ & Fe $415(\mathrm{fy}=415 \mathrm{~N} / \mathrm{mm} 2)$ \\
\hline Plan area & $960 \mathrm{~m} 2$ \\
\hline Number of stories & $\mathrm{G}+20$ \\
\hline Floor height & $3.5 \mathrm{~m}$ \\
\hline \multirow{4}{*}{ Column size: } & $230 \times 1500 \mathrm{~mm}$ \\
\cline { 2 - 2 } & $300 \times 1500 \mathrm{~mm}$ \\
\cline { 2 - 2 } & $230 \times 1800 \mathrm{~mm}$ \\
\cline { 2 - 2 } & $300 \times 1800 \mathrm{~mm}$ \\
\cline { 2 - 2 } & $\begin{array}{l}\text { T shape } \\
\mathrm{B}=1.5 \mathrm{~m}, \mathrm{D}=1.5, \mathrm{tw} \& \mathrm{tf}=0.3 \mathrm{~m}\end{array}$ \\
\hline Beam size & $230 \times 600 \mathrm{~mm}$ \\
\hline Slab thickness & $130 \mathrm{~mm}$ \\
\hline Wall thickness & $230 \mathrm{~mm}$ \\
\hline Density of concrete & $25 \mathrm{~N} / \mathrm{mm} 3$ \\
\hline $\begin{array}{l}\text { Live Load on Floor and } \\
\text { roof }\end{array}$ & $3 \mathrm{KN} / \mathrm{m} 2$ and $1.5 \mathrm{KN} / \mathrm{m} 2$ \\
\hline Density of wall & $20 \mathrm{~N} / \mathrm{mm} 3$ \\
\hline Diaphragm & semi rigid diaphragm \\
\hline Plan irregularity: & $\mathrm{H} \mathrm{shape}$ \\
\hline
\end{tabular}

a) Model- 1: H shape plan with rectangular columns. (Fig 3)

b) Model-2: $\mathrm{H}$ shape plan with rectangular along with $4 \mathrm{~T}$ shaped columns. (Fig 4)

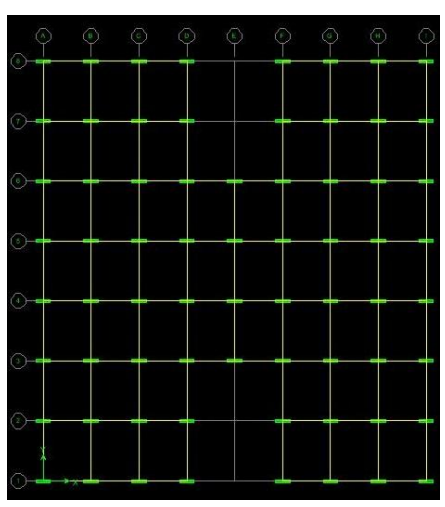

Fig.-3: Plan of $\mathrm{H}$ shaped building

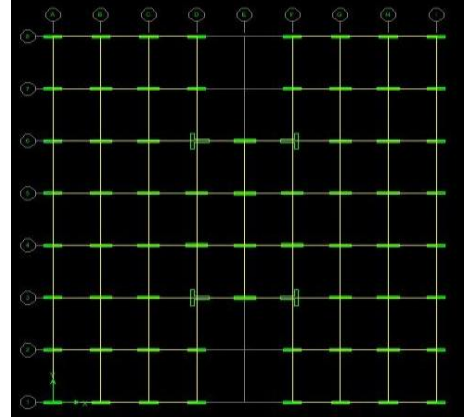

Fig-.4: Plan of $\mathrm{H}$ shaped building (along with $\mathrm{T}$ shaped column)

\section{RESULTS AND DISCUSSION}

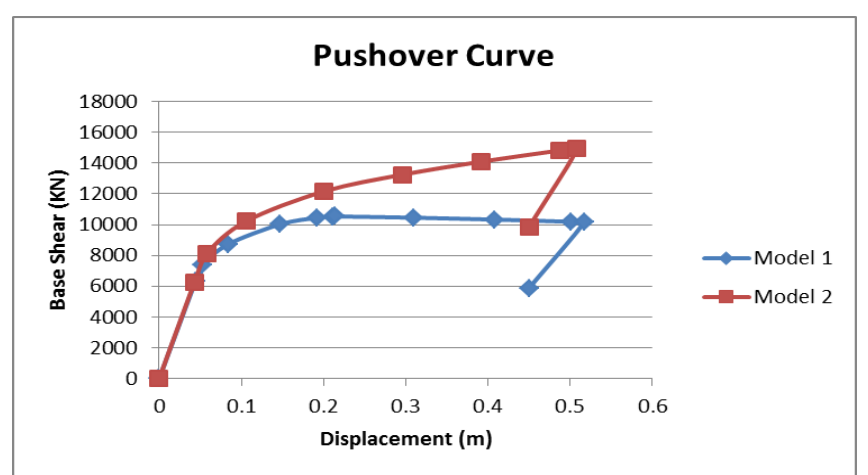

Fig-.5: Post elastic behaviour of bare frame for Pushover Load $-\mathrm{EQX}$

The resulting pushover curve for the $\mathrm{G}+20$ building is shown in Fig 5. The curve is initially linear but starts to deviate from linearity as the beams and columns undergo inelastic actions. When the building is pushed into the inelastic range, the curve become linear again but with a smaller slope. The curve could be approximated by a bilinear relationship. In the present case for static pushover load EQX, Model 2 shows $13.5 \%$ more base shear at $0.2 \mathrm{~m}$ displacement than Model 1 .

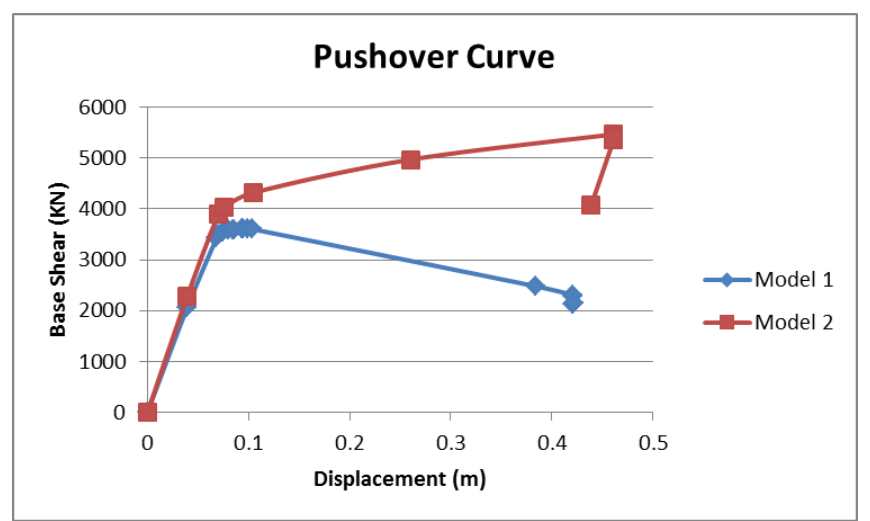

Fig.-6: Post elastic behaviour of bare frame for Pushover Load $-\mathrm{EQY}$ 
In Fig.6 for static pushover load EQY, Model-2 shows $8.34 \%$ more base shear at $0.1 \mathrm{~m}$ displacement than Model-1.Here the performance increment of the Model-2 is acceptable. So the presence of $\mathrm{T}$ shape column will affect in $\mathrm{Y}$ direction also. The curve is initially linear but starts to deviate from linearity as the beams and columns undergo inelastic actions. The both curve shows good ductile behaviour.

\subsection{Capacity and Demand Spectrum of Bare Frame}

for $C_{a}=0.22$ and $C_{v}=0.32$ (Equivalent value for Type

\section{II soil and Zone III)}

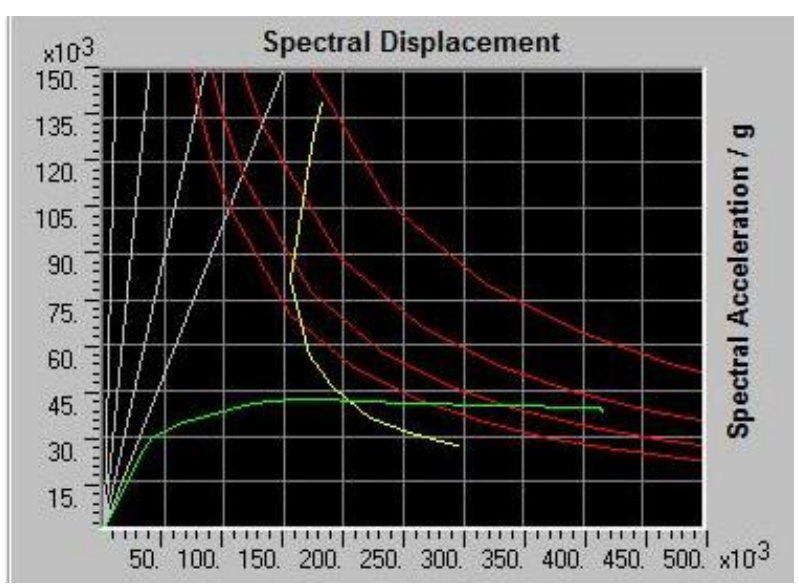

Fig-7: Capacity and demand Spectrum of Model-1, Pushover Load- EQX

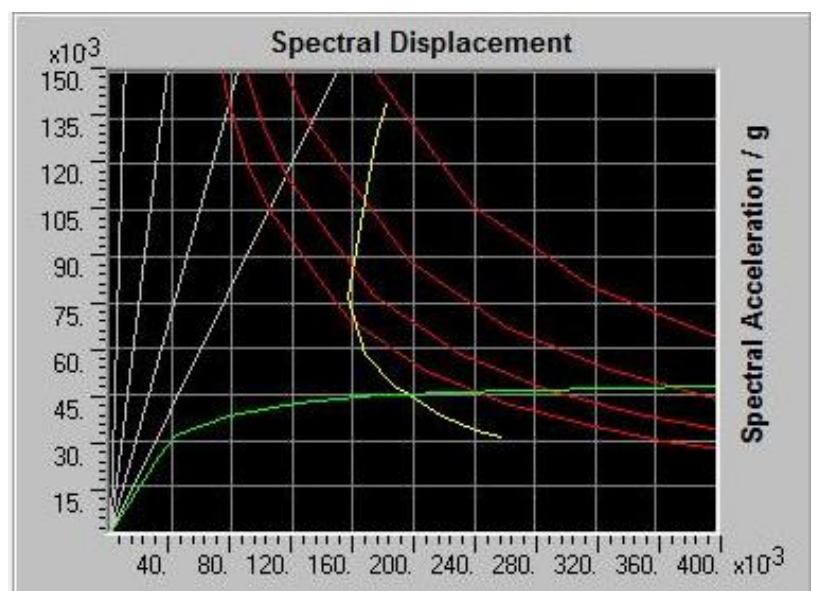

Fig-8: Capacity and demand Spectrum of Model-2, Pushover Load- EQX

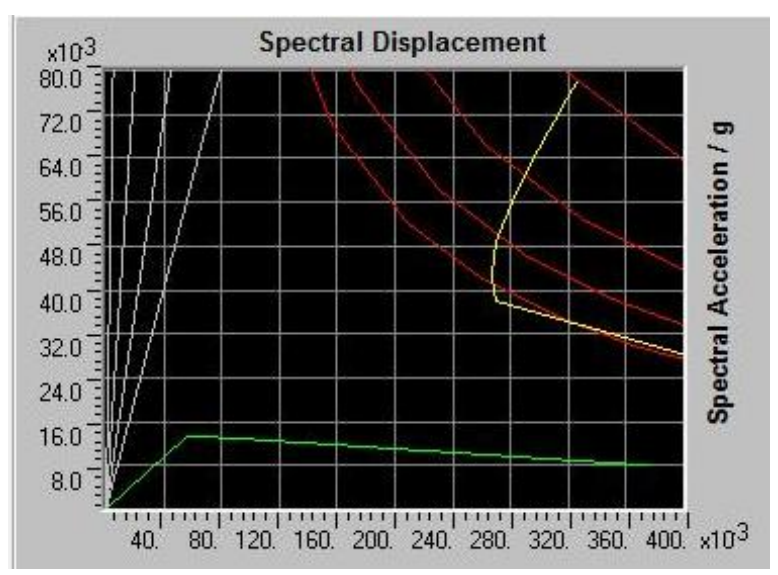

Fig-9: Capacity and demand Spectrum of Model-1 Pushover Load- EQY

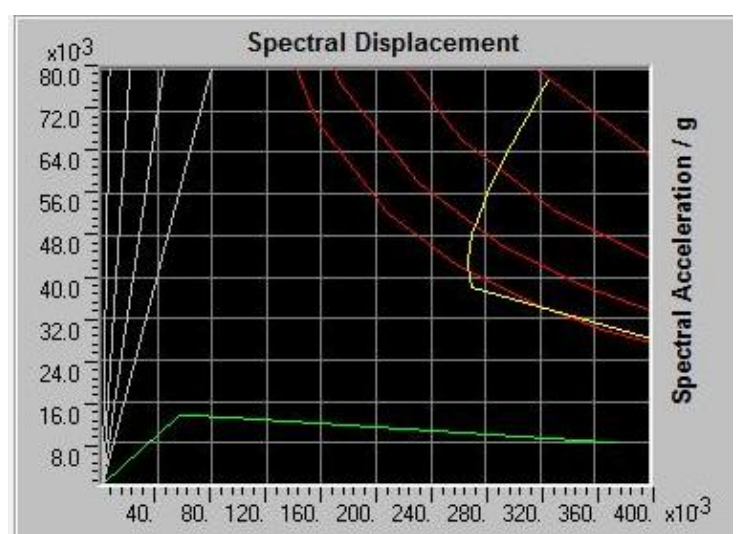

Fig-10: Capacity and demand Spectrum of Model-2 Pushover Load- EQY

Table-2: Performance Point of bare frame obtained from Capacity Spectrum Method

\begin{tabular}{|l|l|l|}
\hline $\begin{array}{l}\text { Type of Pushover } \\
\text { Load }\end{array}$ & $\begin{array}{l}\text { Type of RC } \\
\text { Frame }\end{array}$ & $\begin{array}{l}\text { Performance Point } \\
\text { (VBP, Sroof) }\end{array}$ \\
\hline \multirow{2}{*}{ Static- EQX } & Model - 1 & $(10468.8,0.249)$ \\
\cline { 2 - 3 } & Model - 2 & $(11438.5,0.347)$ \\
\hline \multirow{2}{*}{ Static-EQY } & Model - 1 & N/A \\
\cline { 2 - 3 } & Model - 2 & N/A \\
\hline
\end{tabular}

From the Fig. 7 and Fig. 8 it is observed that the demand curve tend to intersect the capacity curve in the building performance level of Life Safety Level, Where substantial damage has occurred to the structure, and it may have lost a significant amount of its original stiffness. However, a substantial margin remains for additional lateral deformation before collapse would occur.

From the Fig.9 and Fig.10 it is observed that the demand curve do not intersect the capacity curve. Hence the performance of the structure is poor in $\mathrm{Y}$ direction. 


\section{CONCLUSIONS}

The performance of reinforced concrete frames was investigated using the pushover Analysis. These are the conclusions drawn from the analysis: The pushover analysis is a relatively simple way to explore the non-linear behaviour of Buildings. When earthquake load is applied in X direction, it is found that model with $\mathrm{T}$ shaped column can resist more base shear than Model with rectangular column. When earthquake load is applied in Y direction, it is found that model with $\mathrm{T}$ shaped column can resist more base shear than Model with rectangular column. But the percentage increment is acceptable. The results obtained in terms of demand, capacity spectra shows real behaviour of structures.

\section{REFERENCES}

[1]. Bachmann H. Seismic conceptual design of buildingsbasic principles for engineers, architects, building owners, \& authorities. BWG, Biel: Swiss Federal Office for Water and Geology, Swiss Agency for Development and Cooperation; 2003.

[2]. Saiidi M, Sozen MA. Simple nonlinear seismic analysis of $\mathrm{R} / \mathrm{C}$ structures. Journal of the Structural Division, ASCE 1981; 107(ST5):937-51.

[3]. Fajfar P, Gaspersic P. The N2 method for the seismic damage analysis of RC buildings. Earthquake Engineering and Structural Dynamics 1996; 25:31-46.

[4]. Bracci JM, Kunnath SK, Reinhorn AM. Seismic performance and retrofit evaluation of reinforced concrete structures. Journal of Structural Engineering, ASCE 1997; 123(1):3-10.

[5]. FEMA. NEHRP guidelines for the seismic rehabilitation of buildings. FEMA 273, Federal Emergency Management Agency, 1996.

[6]. SEAOC. Performance based seismic engineering of buildings. Vision 2000 Committee, Structural Engineers Association of California, Sacramento, CA, 1995. 